\title{
The Importance of Innovation for Small-Scale Metallurgical Industries: Multiple Case Study on Innovation Management
}

\author{
Marcos Oliveira Morais (Corresponding author) \\ Phd student - Dept. of Production Engineering, Paulista University \\ Antonio Sérgio Brejão \\ Phd - Dept. of Production Engineering, Paulista University \\ Marcelo Bernardino Araújo \\ Phd - Dept. of Production Engineering, Paulista University \\ Pedro Luiz de Oliveira Costa Neto \\ Professor in Dept. of Production Engineering, Paulista University
}

Received: June 24, 2018 Accepted: July 12, 2018 Online published: July 16, 2018

doi:10.5296/ijhrs.v8i3.13388ＵRL: https://doi.org/10.5296/ijhrs.v8i3.13388

\begin{abstract}
This research aims to identify how specialists of small metallurgical companies analyze the question regarding the search for innovation. Then, we conducted a survey in five companies from the sectors of aluminum casting under pressure, plastic injection, and lighting. It is also possible to see that for small companies, partnership issues become relevant in the context of innovation together with the interaction between the company and employees. This research indicates that innovate became the way to remain competitive, since the high Brazilian tax burden prejudice the gains of the companies, enabling both technological and organizational advances. It is a multiple case study paper in the secondary sector.
\end{abstract}

Keywords: innovation, small business, strategy 


\section{Introduction}

Small enterprises play a key role in the economy, generating jobs and income in any country. These companies are increasingly dependent on technological development and innovation to ensure their survival in the market. Therefore, the generation of innovation and technical qualification are important elements for these organizations and especially for their workforce.

Innovation becomes an essential tool since it is based on knowledge. It makes the organization innovative, increasing the search for new products, processes and/or services, raising the potential of the organization and making it more competitive. It can be affirmed that there is a close relation between innovation and competitiveness since these are linked to a greater flow of goods, capital, services, and knowledge (Caron, 2003).

According to the Brazilian Complementary Law No. 123 (Brasil, 2006), innovation is the main tool of competitiveness for a company. Consequently, a company that does not innovate is driven to stagnation, losing its competition power over time.

Innovation represents the possibility of a differential development and, specifically, increasing an industry productivity and creating new levels of competitive advantages, then the innovative capacity is a crucial element to evaluate the potential of the sector of the economy (Quandt, 2012).

\section{Literature Review}

\subsection{The Essence of Innovation}

Innovation is the subject of several discussions about competitiveness in the business environment and also in the academic environment. New methods and directions become essential in people and organizations 'daily life since a competitive advantage is a key point for development in order to survive in any environment. According to Tidd and Bessant (2009), the competitive advantages may even come from other factors, such as the assets of a company.

Innovation is the process resulting from new products wherein the consumers are not familiar with new methods of production, new markets, new suppliers, raw materials or inputs and, finally, new organizations of any industrial sector (Schumpeter, 1982).

The economic scenario is changing in favor of organizations that are able to introduce innovative products in their portfolio, using technological advances and knowledge in their production processes and services. In this way, we can visualize the different perspectives of innovation, classified as administrative and technical innovations (Kimberly \& Evanisko, 1981) innovation in organizational work, product innovations and innovations in processes (Whipp \& Clark, 1986).

Nelson (1991) argues that companies need a set of competencies or capabilities to innovate in ways that they can survive in the long run. In order to not lose their position to the competitors, an organization will obsessively seek for the increase of added value to its 
products (Knox, 2002). The pursuit of improvement for its products can result in innovations, generating gains for the organization.

The importance of innovation for the survival of an individualized business is increasing according to the economic growth in the national and international proportions. There are indications that innovation positively affects the productivity of a company. The companies that launch new technological products in the market have an average productivity far superior comparing to those that do not innovate (Arbache 2005). Figure 1 illustrates the stages between innovation and achievement in the organization.

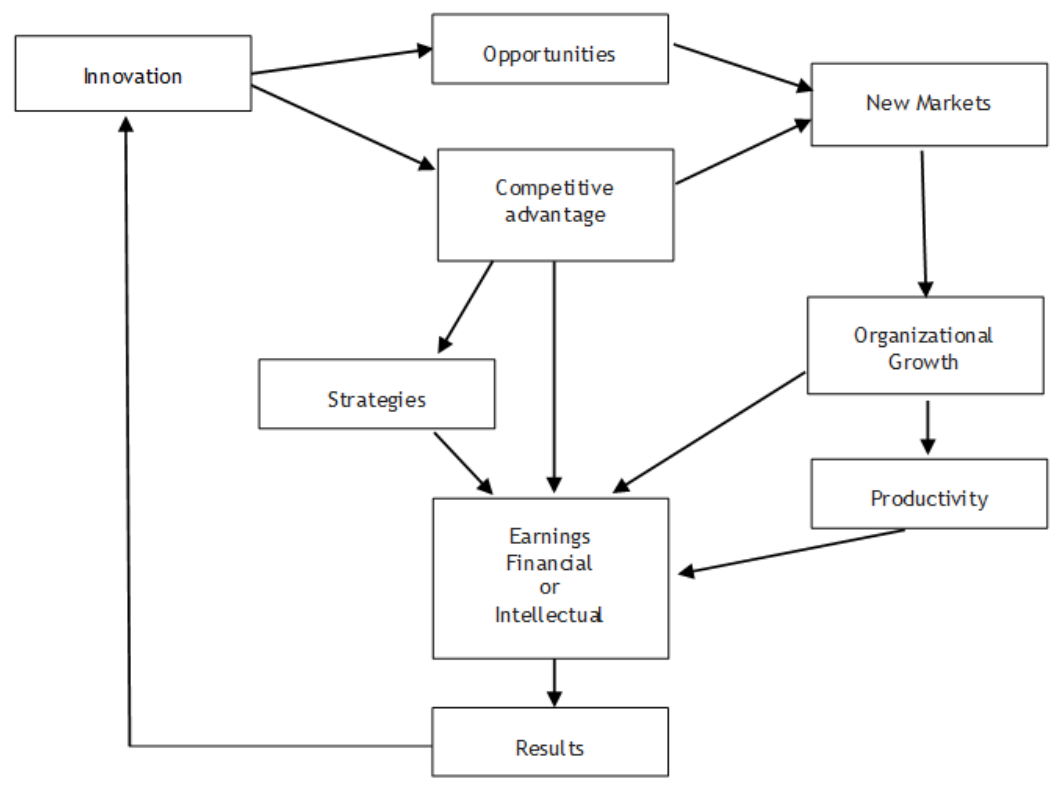

Figure 1. Phases between innovation and results.

Source: Author's own.

According Knox (2002) and Arbache (2005) innovation triggers a series of steps inside and outside the organization, generating either financial or intellectual gains, making an essential integration among the several stages in the company that optimizes its performance.

The development of a competitive strategy of innovation based on the purpose of how the company will compete in the market, as well as the strategy of a profitable and sustainable position against the competitors (Passos, 2014).

Innovation is characterized by the discovery, search, experimentation, and development of new products, processes, and organizational management improvement. It is an interactive process where both the economic and social agents participate in aggregating different types of information and knowledge that must have a direct relationship with regional agents (Jacoski et al., 2014).

\subsection{Innovation Management}

The area of innovation, as well as other areas of competence of a company, needs management, as innovation is an ongoing process. All activities involved in the innovation 


\section{Macrothink}

International Journal of Human Resource Studies

ISSN 2162-3058

2018, Vol. 8, No. 3

process can be influenced by both internally and externally process, interfering in the final result of the innovation (OECD, 1997).

Managing innovation is only possible through the management of people, or the intellectual capital since they are the main part to improve the value of companies due to the difficult to measure companies' intangible assets. In order to facilitate the innovation process, it is recommended that organizations build and stimulate network cooperation to promote the interaction among employees, companies, academic and governmental institutions in order to raise intangible capital (Carol et al., 2008 and Guimarães, 2011).

More companies are identifying the importance of innovation management. As they are motivated they tend to become more participative, receptive and creative, supporting the process of innovation. Imagination, initiative, creativity, commitment are factors, when properly used, that contribute to the process of knowledge and innovation (Canongia et al., 2004).

A worth noting point is that a new idea in the company can arise from people who are in the day-to-day operation. Innovation must also be followed by a cultural change in the organization, and the manager is for the change and to figure out the innovation strategy for the company's goals (Bicalho et al., 2012).

Complement that innovation is a process that must be managed connected strategy adopted by the company (Scherer and Carlomagno 2016). Corroborate that organizations must define the basic business strategy, determining how innovation can make it feasible (Tidd and Bessant, 2009). Thus, the problem is not the sparse ways to gain a competitive advantage for innovation, but knowing which one to choose. Figure 2 illustrates the interaction between the various processes for managing innovation in organizations.

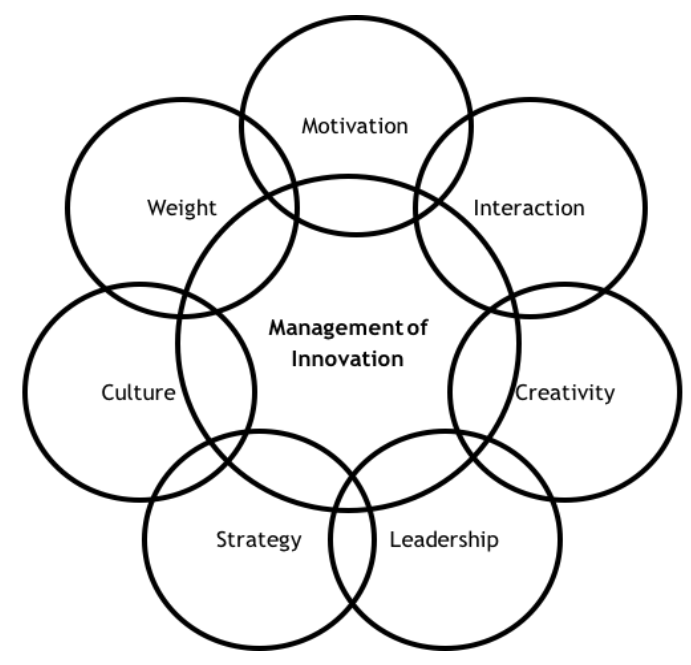

Figure 2. Factors of interaction and management of innovation

Source: Author's own.

Innovation management, among other aspects, deals with the organization and management of human and financial resources with the purpose of sharing and increasing the generation of 
new knowledge, ideas for new products and processes and improvement for the already existing ones, acting directly on the organization's performance (Coral et al., 2008).

Innovations are not created spontaneously but they are the result of interactions, efforts and a propitious environment inside the company where the ideas are cultivated and not suppressed.

Innovations are not simply the fruit of spontaneous generation, nor created in the vacuum: they are results of interactions, efforts, and created in a propitious environment, where ideas are not curtailed and thereby thrive. There are organizations that are characterized by promoting innovation, products, processes, services, and businesses (Scherer and Carlomagno, 2016).

\subsection{Management of Innovation in Small Enterprises}

The innovative companies play a prominent role in the economic development of the most competitive nations, because of both higher profitability and the nature of the jobs they generate, which demand higher qualification and consequently, providing better remuneration (Porter 2004).

Although small enterprises mostly have a cost constraint on new developments, they realize the importance of innovation, surpassing this obstacle due to partnerships mainly with their customers.

Souza (2003) points out that an important difficulty of using the tools of technology management and innovation by small companies is the cost of the systems and the implementation of the internal structures for technological management, considering only the variable costs.

The most used indicator in Brazil is presented in Table 1, which identifies the size of the companies in terms of the number of employees, based on IBGE - Brazilian Institute of Geography and Statistics.

Table 1. Classification of companies 'size according to IBGE

\begin{tabular}{ccc}
\hline Classification & Industry & Trade and Service \\
\hline Micro & Up to 19 employees & Up to 9 employees \\
Small & From 20 to 99 employees & From 10 to 49 employees \\
Average & From 100 to 499 employees & From 50 to 99 employees \\
Big & More than 500 employees & More than 100 employees \\
\hline
\end{tabular}

Small companies possess a natural competitive advantage when compared to large companies: the size. Small companies are easier to manage, more flexible and leaner, consisting of more adaptable processes, agiler and less bureaucratic. For Matt and Rauch (2013), the small and medium companies have an advantage toward higher productivity.

\section{Materials and Methods}

A research of multiple cases study was conducted since it is more consistent when compared to the single case study (Yin, 2014). The research was carried out with specialists and 
managers of companies, allowing a deeper understanding.

Five specialists of the product developing a department of metallurgical companies, where innovation is a differential for both their products and customers' products were selected for this research. These companies operate in several segments such as electronics, automotive, white line, lighting, and toys. All the companies are of national capital ones located in the State of São Paulo, and they are classified as up to eighty employees.

Data were collected from December 2017 to January 2018, were interviewed managers and specialists of these organizations. The interviews were structured on closed questions, for a better analysis. We have decided not to revise their names as there are competitors in some segments.

\subsection{Methodology}

It is necessary to describe the companies that participated in order to obtain a better understanding of the studied scenario. As described in Table 2, all the companies have a product development department, directly or indirectly. They are all working on the metallurgical sector, highlighting the importance of this industry to the economy as well as to innovation.

Table 2. Organizations 'profile

\begin{tabular}{cl}
\hline Profile & \multicolumn{1}{c}{ Characteristics of the organization } \\
\hline Company A & $\begin{array}{l}\text { Metallurgical company of casting aluminum under pressure, acting in the } \\
\text { automotive segment, supplier, all the developments are made in partnership } \\
\text { with clients. It has about seventy employees, founded in 1965. } \\
\text { Metallurgical foundry of aluminum under pressure company, a supplier of } \\
\text { automotive and white line industries. Owner of own products and the area of } \\
\text { product development. It has about sixty employees, founded in 1999. } \\
\text { Metallurgical company of injection of plastics. Provider of service to the } \\
\text { white line, electrical and electronic products segment, working in product } \\
\text { development with its customers, sectors of product and process engineering. }\end{array}$ \\
$\begin{array}{l}\text { Seventy-five employees, founded in 1982. } \\
\text { Metallurgical company of plastic injection and assembly of electronic }\end{array}$ \\
equipment holder of products with a development of products department, \\
company Dertified by INMETRO, assembling and distribution products to the \\
wholesale market. Seventy employees, founded in 1991. \\
The metallurgical company manufacturing reflectors to the civil construction \\
and public lighting, with development and manufacturing department for \\
own products and resale of imported ones. Approximately seventy-five \\
employees, founded in 1985.
\end{tabular}

\section{Discussion and Results}

\subsection{The Importance Innovation to Company}

The five organizations' interviewees agree that innovation is the basis of the organizational sustainability as a key factor for the organization's permanence in the market. According to the interviewees, the top managers must be engaged with innovation, what would facilitate the dissemination of the knowledge throughout the structure. Another important point according to the interviewees remains in the availability of resources and qualification of the 
employees since they become the main part of the process. Serafim (2011) understands innovation as a very efficient and competitive strategy for organizational performance, based on the assumption that the customer is the focus of the innovation process. The company must create value for the customers, knowing their needs and expectations, thus, innovation becomes a means to satisfy and retain customers.

The development of new strategies according to the interviewees allows the competitive potential of the organization in order to obtain relevance when compared to its competitors. This advantage can be extended when combined with innovation, once its products become unique in the market. They also unanimously agree that without innovations they would already be out of the market, or acting only in the aftermarket, reducing their action field and visibility. Kuczmarski (1998) emphasizes that innovation must be tuned with the organizational strategies, the internal and external environments, through identification of essential competencies and opportunities, abilities to maintain a culture, innovative projects and the creation of routines that incorporate the innovative awareness in the day-to-day of the organization.

All interviewees agree that innovation effectively brings positive results to the organization and the people. In some cases, regarding the production processes, innovations are created unexpectedly, when employees create a spontaneous improvement and inform the development department that monitors a possible productive gain without losing the existing quality in all subsequent processes. Sometimes innovations are elaborated by the technical department, stimulating the creativity within the organization and how it should be carried out in all departments. According to Tidd and Bessant (2009), stimulating creativity and innovation requires more than a set of tools and techniques to create ideas. The process is centered on methodologies and strategies towards solution or outputs.

According to the interviewees, only the company $\mathrm{D}$ does not agree to share innovation, once they point out that it is a possibility for the organization to gain a competitive advantage over its competitors. The other interviewees agree that the exchange of information is the best way for an organizational and personal growth, allowing the reduction of possible errors due to learned lessons. In innovation, the sharing of challenges allows companies to deal with the world of uncertainties, constantly trying new opportunities and possibilities (Tidd \& Bessant, 2009).

\section{Conclusion}

This article aimed to verify and analyze which specialists of small metallurgical companies use innovation as a way to create a competitive differential work.

Based on the characteristics of the surveyed companies, we concluded that all managers are aware of the importance of innovation as well as their difficulties, based on the organization size.

It is worth noting that the great impact for small companies is related to the cost of this structure and a partnership allows minimizing it. In order to overcome the new technology challenges, innovation becomes an essential component to remains in the market. 
In general, we observed how small companies visualize the innovation issue and the strategies such as motivation, creativity, and interaction can help in the development process, making it possible to raise the potential of the organization and the people involved.

The limitations of this study are: the companies analyzed are from the metallurgical and small-scale industries; the responses were based on the experiences of the interviewees; and a particular region of the country, restricting any type of comparison.

It is suggested for future studies, surveys to companies from different sectors, as well as the size of the organization and the enlargement of the sample.

\section{Acknowledgment}

The authors would like to thank CAPES (Coordenação de Aperfeiçoamento de Pessoal de Nível Superior) and UNIP (Universidade Paulista) for the financial support to develop this work.

\section{References}

Arbache, J. S. (2005). Inovações tecnológicas e exportações afetam o tamanho $e$ produtividade das firmas manufatureiras: Evidências para o Brasil (Chapter 12). In: DE NEGRI, J. A. \& SALERNO, M. S. (Org) Inovações, padrões tecnológicos e desempenho das firmas industriais brasileiras, IPEA

Bicalho, T., Faria, W., Pinheiro, H., \& Vianna, M. (2015). A ordem é inovar. Revista Brasileira de Administração, 104, 24-29

Brasil. (2006). Lei Complementar $n^{\circ} 123$, de 14 de dezembro de 2006. Institui o Estatuto Nacional da Microempresa e da Empresa de Pequeno Porte, Diário Oficial [da] República Federativa do Brasil

Canongia, C., Santos, D. M., Santos, M. M., \& Zackiewicz, M., (2004). Foresight, inteligência competitiva e gestão do conhecimento: Instrumentos para a gestão da inovação, Gestão \& Produção, 11, 231-238

Caron, A. (2003). Inovações tecnológicas nas pequenas e médias empresas industriais em tempos de globalização - o caso do Paraná. Tese de Doutorado em Engenharia de Produção, Universidade Federal de Santa Catarina

Coral, E., Ogliari, A., \& Abreu, A. F. (2008). Gestão integrada da inovação: estratégia, organização e desenvolvimento de produtos. Atlas

Guimarães, S. K. (2011). Produção do Conhecimento Científico e Inovação: Desafios do novo padrão de desenvolvimento, Caderno $\mathrm{CRH}, 24,461-465$

IBGE. Instituto Brasileiro de Geografia e Estatística. Brasil. [Online] Avalible at: http://www.ibge.gov.br (December 1, 2017)

Jacoski, C. A., Dallacorte, C., Bieger, B. N., \& Deimling, M. F. (2014). Análise do desempenho da inovação regional - Um estudo de caso na indústria. Revista de Administração e Inovação, 11, 71-88

Kimberly, J. R., \& Evanisko, M. J. (1981). Organizational innovation: The influence of individual, organizational, and contextual factors on hospital adoption of technological and 
administrative innovations. Academy of Management Journal, 24, 689-713

Knox, S. (2002). The boardroom agenda: Developing the innovative organization. Corporate Governance: The International Journal of Business in Society, 2, 27-36

Kuczmarski, T. D. (1998). Por uma consciência inovadora. HSM Management, 5, 62-68

Matt, D., \& Rauch, E. (2013). Implementation of lean production in small sized enterprises. Procedia CIRP, 12, 420-425

Nelson, R. R. (1991). Why do firms differ, and how does it matter? Strategic Management Journal, 12, 61-74

OECD. (1997). Manual de OSLO: Diretrizes para coleta e interpretação de dados sobre inovação, Finep

Passos, A. (2014). Inteligência competitiva é estratégia. Revista Inteligência Competitiva, 4, 14-16

Porter, M. E. (2004). Estratégia competitiva: Técnicas para análise de indústrias e da concorrência, Elsevier

Quandt, C. O. (2012). Redes de cooperação e inovação localizada: Estudo de caso de um arranjo produtivo local. Revista de Administração e Inovação, 9, 141-166

Scherer, F. O., \& Carlomagno, M. S. (2016). Gestão da inovação na prática: Como aplicar conceitos e ferramentas para alavancar a inovação. Atlas

Schumpeter, J. A. (1982). Teoria do desenvolvimento econômico: Uma investigação sobre lucros, capital, crédito, juro e o ciclo econômico. Abril Cultural

Serafim, L. E. (2011). O poder da inovação: Como alavancar a inovação na sua empresa. Saraiva

Souza, D. L. O. (2003). Ferramentas de gestão de tecnologia: Um diagnóstico de utilização nas pequenas e médias empresas industriais da região de Curitiba. Dissertação de Mestrado em Tecnologia, Centro Federal de Educação Tecnológica do Paraná

Tidd, J., \& Bessant, J. (2009). Managing innovation: Integrating technological. Market and Organizational Change, Wiley

Whipp, R., \& Clark, P. (1986). Innovation and the auto industry: Product, process, and work organization. Macmillan

Yin, R. K. (2014). Case study research: Design and methods. Sage Publications (5th Edition)

\section{Copyright Disclaimer}

Copyright for this article is retained by the author(s), with first publication rights granted to the journal.

This is an open-access article distributed under the terms and conditions of the Creative Commons Attribution license (http://creativecommons.org/licenses/by/4.0/). 